\title{
STRUCTURAL MODIFICATION OF CIPROFLOXACIN AND NORFLOXACIN FOR SEARCHING NEW ANTIBIOTICS TO COMBAT DRUG-RESISTANT BACTERIA
}

\author{
Halyna Hryhoriv, Illia Mariutsa, Sergiy M. Kovalenko, Lyudmila Sidorenko, \\ Lina Perekhoda, Nataliia Filimonova, Olga Geyderikh, Victoriya Georgiyants
}

\begin{abstract}
The aim of the work. Among all the representatives of four generations of fluoroquinolones ciprofloxacin (CIPRO) and norfloxacin (NOR) remain widely used and prescribed antibiotics in clinical practice. However, the problem of resistance towards them is gradually increasing. Thus, our investigation is dedicated to chemical modification of $C-7$ position of Ciprofloxacin and Norfloxacin ring as a promising solution to combat antibiotic resistance and open a pathway towards convenient synthesis of new fluoroquinolones derivatives.

Materials and methods. The subjects of the research were N-piperazine-substituted ciprofloxacin and norfloxacin. The methods of molecular docking and organic synthesis were applied in the study. The structures of the obtained compounds were confirmed by ${ }^{1} \mathrm{H} N M R,{ }^{13} \mathrm{C} N M R,{ }^{19} \mathrm{~F} N M R, L C / M S, I R$, UV spectroscopy. The antimicrobial activity was measured by the method of double serial dilutions against Staphylococcus aureus (ATCC 25923), Escherichia coli (ATCC 25922), Bacillus subtilis (ATCC 6633), Pseudomonas aeruginosa (ATCC 27853), Candida albicans (NCTC 885-653) and diffusion in agar method against clinical strains.

The results. 7-(4-(2-Cyanoacetyl)piperazin-1-yl)-1-R-6-fluoro-4-oxo-1,4-dihydroquinoline-3-carboxylic acids were synthesized and their structures were confirmed. The obtained compounds showed the antibacterial activity on the reference level for double dilution method and exceeded control for "well" method.

Conclusions. The current investigation revealed the promising route for the expanding of the existing fluoroquinolones diversity. Pharmacodynamics and pharmacokinetics changes could be achieved by chemical modifications of C-7 position of the initial ring. Further research utilizing the obtained compounds as starting ones opens a promising way to novel active molecules synthesis and combating the problem of antibiotic resistance
\end{abstract}

Keywords: fluoroquinolones, ciprofloxacin, norfloxacin, synthesis, antibiotic resistance, molecular docking, antibacterial activity

How to cite:

Hryhoriv, H., Mariutsa, I., Kovalenko, S. M., Sidorenko, L., Perekhoda, L., Filimonova, N., Geyderikh, O., Georgiyants, V. (2021). Structural modification of ciprofloxacin and norfloxacin for searching new antibiotics to combat drug-resistant bacteria. ScienceRise: Pharmaceutical Science, 5 (33), 4-11. doi: http://doi.org/10.15587/2519-4852.2021.242997

(C) The Author(s) 2021

This is an open access article under the Creative Commons CC BY license hydrate

\section{Introduction}

The World Health Organization refers to the problem of antibiotic resistance as of one of the huge threats to global health and security [1]. Due to its appearance hospital stays become longer, medical costs and mortality level are increased [2]. All over the world people are influenced by antibiotic resistance as an economic burden that decreases the total quality of their lives [3].

Altogether such an extremely negative impact of antibiotic resistance on the health and economic systems definitely needed to be combated. For this purpose nowadays there are at least two global strategies. Firstly, the methods to control the spread of antibiotic resistance towards existing medicines must be created and implied in the health care systems of all countries. Secondly, the scientific community has to intensify the development and implementation of new biologically active molecules that can become novel potent antimicrobials [4].
The second issue is currently under investigation by medicinal chemists and also appears to have two suggestions to solve it. On the one hand, totally new compounds can be created by the powers of organic synthesis. In this case preliminary molecular docking studies appear to be a helpful tool in order to predict probable mechanisms and types of biological activity. Combination of these two processes - prediction and purposeful synthesis - allows obtaining novel promising molecules without even the slightest hint of resistance towards them. On the other hand, one can modify the existing compounds that are already well-known for their antibacterial properties and change their structures in a desirable way.

Talking about fluoroquinolones we must admit that existing now four generations were created using the second approach. Furthermore, the investigations in this area are still in progress [5]. 
It is worth to mention that fluoroquinolones possess the unique mechanism of action. Their targets in the bacterial cell are enzymes topoisomerase IV, which is responsible for the organization of the spatial arrangement of the chromosome within the bacterium and the division of chromosomes in the process of cell division, and DNA gyrase, which is responsible for the process of supercoiling of bacterial DNA [6]. That means that resistance towards this class of antibiotics may occur due to two mechanisms: modification of the targets (mutations in both the DNA gyrase and topoisomerase IV genes) and active excretion of medicine from a microbial cell.

However, even in such a situation antibiotic resistance to fluoroquinolones, especially towards representatives of second generation Ciprofloxacin and Norfloxacin, becomes a major clinical issue that increases throughout the world [7, 8].

Therefore, continuing our investigations in the area of quinolone chemistry [9-11] and using previous synthetic experience we decided to accept such challenging task and find a way to modify Ciprofloxacin and Norfloxacin in order to fight the problem of antibiotic resistance.

The aim. To synthesize the C-7 substituted derivatives of Ciprofloxacin and Norfloxacin that could be further utilized in the processes of novel fluoroquinolones creation, provide molecular docking studies for these novel structures and check the changes in their antimicrobial activity comparing to the parent structures.

\section{Planning (methodology) of research}

From the chemist's viewpoint fluoroquinolones are attractive molecules due to the wide variety of possible structural modifications. However, the C-7 position plays a key role in their binding to cell targets, therefore, helping to overcome resistance. Additionally, the binding to human topoisomerase II $\alpha$ is also mediated by the C-7 substituent.

Thus, the obvious pathway towards new fluoroquinolones synthesis is the substitution of Nitrogen in piperazine ring. It should be mentioned that there is evidence about the antimicrobial potency of 4-(2cyanoacetyl)piperazin-1-yl moiety [12-14]. This information lead us to the idea of relatively easy and convenient way towards 7-(4-(2-cyanoacetyl)piperazin-1-yl)-1R-6-fluoro-4-oxo-1,4-dihydroquinoline-3-carboxylic acids synthesis.

Moreover, we should emphasize that these scaffolds reveal high synthetic potential and could be further utilized for other modifications, especially for cyclization reactions with a formation of variety of heterocyclic rings (Fig. 1).

In order to design the experiment rationally at first we decided to use in silico molecular docking studies to predict possible mechanisms of the antimicrobial effect and suitability of the chosen structural modification route.

At the second stage we planned to utilize and compare two synthetic techniques as the target compounds can be obtained by two-step or one-step approach. We decided to try them both and compare their efficacy, 'greenness' and suitability in order to choose the best option.

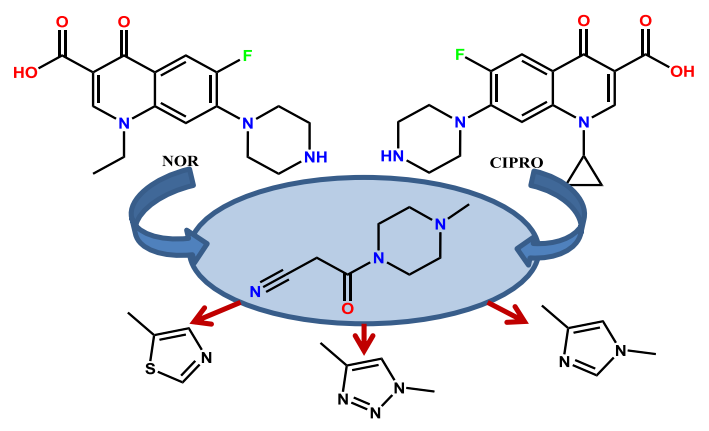

Fig. 1. Synthetic potential of the target scaffolds

At the final stage the antimicrobial screening was planned in order to check the activity of the synthesized compounds and plan further investigations.

\section{Materials and methods}

Molecular docking studies

For receptor-oriented flexible docking, the Autodock 4.2 software package was used. Ligands were prepared using the MGL Tools 1.5.6 program. The Ligand optimization was performed using the Avogadro program. To perform calculations in the Autodock 4.2 program the output formats of the receptor and ligand data were converted to a special PDBQT format. In our previous studies, a similar software package was used $[15,16]$. The active macromolecule centers of antibacterial targets (Staphylococcus aureus DNA Gyrase PDB ID: 2XCR; Mycobacterium tuberculosis topoisomerase II PDB ID:5BTL; Streptococcus pneumoniae topoisomerase IV PDB ID: 4KPF) from the Protein Data Bank (PDB) were used for docking. The receptor maps were made in MGL Tools and AutoGrid programs. Water molecules, ions, and the ligand were removed from the PDB file. mined:

The following docking parameters were deter-

the maximum RMS tolerance for the conformational cluster analysis - $2 \AA$;

the free energy coefficient for torsional degrees of freedom - 0.2983;

the cluster tolerance $-2 \AA$;

the external grid energy - 1000;

the maximum initial energy -0 ; the maximum number of retries - 10000 ;

the number of individuals in the population -150 ; the maximum number of energy evaluations 2500000;

the maximum number of generations -27000 ;

the number of top individuals to survive to the next generation -1 ;

the rate of gene mutation -0.02 ; the rate of crossover - 0.8;

the crossover mode - arithmetic; the $\alpha$-parameter of Gauss distribution - 0 ;

the $\beta$-parameter of Gauss distribution -1 .

The visual analysis of complexes of substances in the active centers for bacterial targets (PDB ID: 2XCR, 5BTL, 4KPF) was performed using the Discovery Studio Visualizer program. 


\section{Experimental chemical part}

The starting fluoroquinolones, ethyl 2-cyanoacetate and solvent are commercially available and, as well as solvents, were purchased by Sigma Aldrich company and were used without further purification.

All NMR spectra were recorded on a Varian MR400 spectrometer with standard pulse sequences operating at $400 \mathrm{MHz}$ for ${ }^{1} \mathrm{H}$ NMR, $101 \mathrm{MHz}$ for ${ }^{13} \mathrm{C}$ NMR and $376 \mathrm{MHz}$ for ${ }^{19} \mathrm{~F}$ NMR. For all NMR spectra, DMSO- $d_{6}$ was used as solvent. Chemical shift values are referenced to residual protons $(\delta 2.49 \mathrm{ppm})$ and carbons $(\delta 39.6 \mathrm{ppm})$ of the solvent as an internal standard. Elemental analysis was performed on a EuroEA-3000 CHNS-O Analyzer. Melting points were determined with a Buchi B-520 melting point apparatus. LC/MS spectra were recorded on a ELSD Alltech 3300 liquid chromatograph equipped with a UV detector $\left(\lambda_{\max } 254 \mathrm{~nm}\right)$, API-150EX massspectrometer and using a Zorbax SB-C18 column, Phenomenex $(100 \times 4 \mathrm{~mm})$ Rapid Resolution HT Cartrige 4.6x30mm, 1.8-Micron. Elution started with $0.1 \mathrm{M}$ solution of $\mathrm{HCOOH}$ in water and ended with $0.1 \mathrm{M}$ solution of $\mathrm{HCOOH}$ in acetonitrile used a linear gradient at a flow rate of $0.15 \mathrm{ml} / \mathrm{min}$ and an analysis cycle time of $25 \mathrm{~min}$. IR spectra in $\mathrm{KBr}$ pellets were recorded on a PerkinElmer 298 spectrophotometer in $\mathrm{KBr}$ pellets. UV/Vis spectra of $0.06 \mathrm{mmol}$ solutions in $\mathrm{MeOH}$ were recorded on a Specord 200 spectrometer.

General procedure for the synthesis of 7-(4-(2cyanoacetyl)piperazin-1-yl)-1-R-6-fluoro-4-oxo-1,4dihydroquinoline-3-carboxylic acid (two-step approach)

\section{Synthesis of $N$-(cyanoacetyl)imidazole (c)}

To the DMF $(100 \mathrm{ml})$ solution of 2-cyanoacetic acid (100 mmol) CDI (120 mmol) was added. The reaction mixture was heated at $80{ }^{\circ} \mathrm{C}$ with stirring for $1 \mathrm{~h}$. After cooling, $50 \mathrm{ml}$ of water was added. The precipitate that formed was filtered off, washed with water.

Yield $12 \mathrm{~g}(89 \%) . \mathrm{Mp}=145-150{ }^{\circ} \mathrm{C} .{ }^{1} \mathrm{H}$ NMR spectrum $\delta$, ppm ${ }^{1} \mathrm{H}$ NMR (400 MHz, DMSO-d6) $\delta 8.20$ (1H, s, H Ar), $7.52(1 \mathrm{H}, \mathrm{d}, \mathrm{J}=7.5 \mathrm{~Hz}, \mathrm{H} \mathrm{Ar}), 7.15(1 \mathrm{H}, \mathrm{d}$, $\mathrm{J}=7.5 \mathrm{~Hz}, \mathrm{H} \mathrm{Ar}), 3.94\left(2 \mathrm{H}, \mathrm{s}, \mathrm{CH}_{2}\right)$. LC/MS m/z ( $\left.\mathrm{I}_{\text {rel }}, \%\right)$ : $135[\mathrm{M}+\mathrm{H}]+(100)$. Calculated, \%: C, 53.33; H, 3.73; N, 31.10; O, 11.84. Found, \%: C, 53.38; H, 3.70; N, 31.12; $\mathrm{O}, 11.80$.

Synthesis of 7-(4-(2-cyanoacetyl)piperazin-1-yl)-1-R6-fluoro-4-oxo-1,4-dihydroquinoline-3-carboxylic acids 1,2

To the DMF (100 ml) solution of 1-R-6-fluoro-4oxo-7-(piperazin-1-yl)-1,4-dihydroquinoline-3-carboxylic acid $(30 \mathrm{mmol}) \mathrm{N}-($ cyanoacetyl)imidazole (c) $(90 \mathrm{mmol})$ was added. The reaction mixture was refluxed with stirring for 4-5 $\mathrm{h}$. After cooling, the precipitate that formed was filtrated, washed with $\mathrm{MeOH}(50 \mathrm{ml})$ and recrystallized from $\mathrm{MeOH}$. Compounds 1,2 were obtained as white solids with yields $89 \%$ and $90 \%$ respectively.

General procedure for the synthesis of 7-(4-(2cyanoacetyl)piperazin-1-yl)-1-R-6-fluoro-4-oxo-1,4-dihydroquinoline-3-carboxylic acid (one-step approach).

To the DMF $(100 \mathrm{ml})$ solution of 2 1-R-6-fluoro-4oxo-7-(piperazin-1-yl)-1,4-dihydroquinoline-3-carboxylic acid $(30 \mathrm{mmol})$ ethyl 2-cyanoacetate $(90 \mathrm{mmol})$ was added. The reaction mixture was refluxed with stirring for $4 \mathrm{~h}$. After cooling, the precipitate that formed was filtered off, washed with $\mathrm{MeOH}(50 \mathrm{ml})$ and recrystallized from $\mathrm{MeOH}$. Compounds 1, 2 were obtained as white solids with yields of 77 and $85 \%$ respectively.

7-(4-(2-Cyanoacetyl)piperazin-1-yl)-1-ethyl-6fluoro-4-oxo-1,4-dihydroquinoline-3-carboxylic acid (1) Two-step approach: yield $10.32 \mathrm{~g}(89 \%)$.

One-step approach: yield $8.93 \mathrm{~g}(77 \%)$.

$\mathrm{M}_{\mathrm{p}}=245-250{ }^{\circ} \mathrm{C} .{ }^{1} \mathrm{H}$ NMR $\delta$, ppm $(400 \mathrm{MHz}$, DMSO-d6) $15.31(1 \mathrm{H}, \mathrm{s}, \mathrm{COOH}), 8.96(1 \mathrm{H}, \mathrm{s}, \mathrm{H}$ Ar), $7.94(1 \mathrm{H}, \mathrm{d}, \mathrm{J}=13.2 \mathrm{~Hz}, \mathrm{H}$ Ar), $7.19(1 \mathrm{H}, \mathrm{d}, \mathrm{J}=7.3 \mathrm{~Hz}, \mathrm{H}$ Ar), $4.59\left(2 \mathrm{H}, \mathrm{q}, \mathrm{J}=7.1 \mathrm{~Hz}, \mathrm{CH}_{2}(\mathrm{Et})\right), 4.12(2 \mathrm{H}, \mathrm{s}$, $\left.\mathrm{CH}_{2}(\mathrm{CN})\right), 3.68\left(2 \mathrm{H}, \mathrm{t}, \mathrm{J}=5.2 \mathrm{~Hz}, \mathrm{CH}_{2}\right.$ (piperazine)), 3.58 $\left(2 \mathrm{H}, \mathrm{t}, \mathrm{J}=5.1 \mathrm{~Hz}, \mathrm{CH}_{2}\right.$ (piperazine)), $3.38\left(2 \mathrm{H}, \mathrm{s}, \mathrm{CH}_{2}\right.$ (piperazine)), $1.42\left(3 \mathrm{H}, \mathrm{t}, \mathrm{J}=7.1 \mathrm{~Hz}, \mathrm{CH}_{3}\right) .{ }^{13} \mathrm{C}$ NMR (101 MHz, DMSO-d6) $\delta 176.11,166.04,161.72,153.98$, $151.50,148.59,145.04,144.93,137.07,119.45,116.09$, 111.34, 111.11, 107.06, 106.16, 49.23, 49.05, 45.01, 41.34, 24.78, 14.34. ${ }^{19} \mathrm{~F}$ NMR (376 MHz, DMSO-d6) $\delta$ 123.90 (dd, J=13.0, 7.1 Hz). LC/MS m/z ( $\left.\mathrm{I}_{\text {rel }}, \%\right): 387.2$ $[\mathrm{M}+\mathrm{H}]+(100)$. IR spectrum $(\mathrm{KBr}), \mathrm{v}, \mathrm{cm}^{-1}: 3427(\mathrm{OH}$, st), 2953, 2924 (C=C, st), 2256 (CN, st), 1697 (C=O carboxylic, st), 1662 (C=O amide, st), 1449, $1480(\mathrm{C}=\mathrm{C}$ phenyl, st), 1247 (C-O, st), $1028(\mathrm{C}=\mathrm{C}, \delta)$. UV/Vis spectrum (MeOH), $\lambda \max \mathrm{nm}(\varepsilon): 235$ (12000), 280 (58000), 319 (12000), 332 (10200). Calculated, \%: C, 59.15; H, 4.900; F, 4.89; N, 14.58; O, 16.50. Found, \%: C, 59.06; H, 4.96; F, 4.92; N, 14.50; O, 16.56.

7-(4-(2-Cyanoacetyl)piperazin-1-yl)-1-cyclopropyl6-fluoro-4-oxo-1,4-dihydroquinoline-3-carboxylic acid (2)

Two-step approach: yield $10.44 \mathrm{~g}(90 \%)$.

One-step approach: yield $9.86 \mathrm{~g}(85 \%)$.

$\mathrm{M}_{\mathrm{p}}=252-256{ }^{\circ} \mathrm{C}$. ${ }^{1} \mathrm{H}$ NMR $\delta$, ppm $(400 \mathrm{MHz}$, DMSO-d6) 15.14 (1H, s, COOH), 8.63 (1H, s, H Ar), 7.88 $(1 \mathrm{H}, \mathrm{d}, \mathrm{J}=13.1 \mathrm{~Hz}, \mathrm{H} \mathrm{Ar}), 7.55(1 \mathrm{H}, \mathrm{d}, \mathrm{J}=7.4 \mathrm{~Hz}, \mathrm{H} \mathrm{Ar})$, $4.13\left(2 \mathrm{H}, \mathrm{s}, \mathrm{CH}_{2}(\mathrm{CN})\right), 3.81(1 \mathrm{H}, \mathrm{tt}, \mathrm{J}=7.3,3.9 \mathrm{~Hz}, \mathrm{CH}$ (cyclopropyl)), $3.70\left(2 \mathrm{H}, \mathrm{t}, \mathrm{J}=5.1 \mathrm{~Hz}, \mathrm{CH}_{2}\right.$ (piperazine)), $3.60\left(2 \mathrm{H}, \mathrm{t}, \mathrm{J}=5.0 \mathrm{~Hz}, \mathrm{CH}_{2}\right.$ (piperazine)), $3.41-3.30(4 \mathrm{H}$, $\mathrm{m}, \mathrm{CH}_{2}$ (piperazine)), $1.30\left(2 \mathrm{H}, \mathrm{dd}, \mathrm{J}=7.5,5.4 \mathrm{~Hz}, \mathrm{CH}_{2}\right.$ (cyclopropyl)), $1.25-1.14$ (2H, m, $\mathrm{CH}_{2}$ (cyclopropyl)). ${ }^{13} \mathrm{C}$ NMR (101 MHz, DMSO-d6) $\delta 176.31,165.83$, $161.73,148.03,144.67,139.10,118.85,116.02,111.13$, 110.94, 106.59, 49.15, 48.89, 44.98, 41.33, 35.84, 24.75, 7.57. ${ }^{19} \mathrm{~F}$ NMR (376 MHz, DMSO-d6) $\delta-124.11$. LC/MS $\mathrm{m} / \mathrm{z}\left(\mathrm{I}_{\text {rel }}, \%\right): 398.2[\mathrm{M}+\mathrm{H}]+(100)$. IR spectrum $(\mathrm{KBr}), v$, $\mathrm{cm}^{-1}$ : $3438(\mathrm{OH}, \mathrm{st}), 2944,2861(\mathrm{C}=\mathrm{C}, \mathrm{st}), 2261(\mathrm{CN}, \mathrm{st})$, $1740(\mathrm{C}=\mathrm{O}$ carboxylic, st), $1650(\mathrm{C}=\mathrm{O}$ amide, st), 1452 $(\mathrm{C}=\mathrm{C}$ phenyl, st), $1244(\mathrm{C}-\mathrm{O}, \mathrm{st}), 1025(\mathrm{C}=\mathrm{C}, \delta)$. UV/Vis spectrum $(\mathrm{MeOH}), \lambda \max \mathrm{nm}(\varepsilon): 230$ (10500), 280 (47000), 319 (15000), 332 (14800). Calculated, \%: C, 60.30; H, 4.81; F, 4.77; N, 14.06; O, 16.06. Found, \%: C, $60.34 ; \mathrm{H}, 4.77 ; \mathrm{F}, 4.75 ; \mathrm{N}, 14.10 ; \mathrm{O}, 16.04$

\section{Experimental microbiological part}

Method of Double Serial Dilutions

The method of double serial dilutions was used in the course of the study [17,v18]. Solutions of the synthesized compounds in DMF were prepared at a concentration of $1 \mathrm{mg} / \mathrm{ml}$.

According to the WHO recommendations the following test-strains were used: Staphylococcus aureus ATCC 25923, Escherichia coli ATCC 25922, Bacillus subtilis ATCC 6633, Pseudomonas aeruginosa ATCC 27853, Candida albicans NCTC 885-653. 
The antimicrobial properties were studied by performing two dilutions of test samples in $2 \mathrm{ml}$ of meat peptone broth (MPB medium No. 1) (a total of 10 tubes). A separate pipette was used for each dilution. After that, $0.2 \mathrm{ml}$ of microbial suspension of each test strain with the appropriate number of microbial cells was added to each tube. Additionally the control was prepared: 2 tubes with $2 \mathrm{ml}$ of used medium in each - control of medium; 2 tubes with $2 \mathrm{ml}$ of used medium with $0.2 \mathrm{ml}$ of microbial suspension of each test strain - growth control of test microorganisms.

The tubes were placed in a thermostat for 18 24 hours. The results were determined visually by the presence or absence of turbidity. The concentration of the compound in the last tube with a clear medium (no visible to the naked eye growth of the test strain) corresponded to the MIC. In the control of the test microorganism growth it should be observed; medium control must be sterile.

Experiments with $\mathrm{C}$. albicans were performed by double dilution of test samples in $2 \mathrm{ml}$ of dextrose broth Saburo (a total of 10 tubes). A separate pipette was used for each dilution. After that, $0.2 \mathrm{ml}$ of the microbial suspension of the test strain with the appropriate number of microbial cells was added to each tube. Additionally the control was prepared: 2 tubes with $2 \mathrm{ml}$ of used medium in each - control of medium; 2 tubes with $2 \mathrm{ml}$ of used medium with $0.2 \mathrm{ml}$ of suspension of the test strain growth control.

The tubes were placed in a thermostat for 1824 hours. The results were determined visually by the presence or absence of turbidity. The concentration of the compound in the last tube with a clear medium (no visible to the naked eye growth of the test strain) corresponded to the MIC. In the control of the growth it should be observed; medium control must be sterile.

The obtained data were analyzed by variation statistics. The significance level $\mathrm{p} \leq 0.05$ was accepted.

\section{Diffusion in Agar Method}

The antimicrobial activity of the compounds synthesized was studied in vitro by the method of diffusion into agar (the method of "wells"), the principle of which is to measure the zone of growth retardation of microorganisms $[17,18]$.

The antimicrobial activity was determined immediately after samples preparation. The studies were per- formed under aseptic conditions. Pure reference cultures were used as test cultures: gram-positive culture of Staphylococcus aureus ATCC 25923, as well as gramnegative culture of Escherichia coli ATCC 25922 and culture of yeast-like fungi Candida albicans ATCC 885653. In addition, clinical strains of Staphylococcus aureus, Escherichia coli and Candida albicans were used in the experiment.

One-day suspensions of bacterial microorganisms in physiological solution were used. The microbial load was $10^{7}$ microbial cells in $1 \mathrm{ml}$ of nutrient medium. Molten agar gel (bottom layer, $\mathrm{V}=10 \mathrm{ml}$ ) was used as the non-inoculated medium for the Petri dishes mounted on a horizontal surface, and meat-peptone agar $(\mathrm{V}=14-15 \mathrm{ml})$ was used as the inoculated medium. Sterile metal thinwalled cylinders (diameter - 8.0 $\pm 0.1 \mathrm{~mm}$, height $10.0 \pm 0.1 \mathrm{~mm}$ ) were used to form the holes. Prior to introduction into the wells, the test substances were dissolved in dimethyl sulfoxide (DMSO).

The results were recorded by measuring the growth retardation zone of microorganisms. Measurements were performed with an accuracy of $1 \mathrm{~mm}$, focusing on the complete absence of visible growth. The value of the zone of growth retardation of pure DMSO was subtracted from the results of analysis of model samples. The antimicrobial activity of experimental samples was evaluated by the diameter of the growth retardation zone of microorganisms: sample; growth retardation zones with a diameter of 11-15 $\mathrm{mm}$ were evaluated as low sensitivity of the culture to the concentration of the active antimicrobial substance; zones of growth retardation with a diameter of $16-25 \mathrm{~mm}$ - as an indicator of the sensitivity of the strain of the microorganism to the test sample; the growth retardation zone, the diameter of which exceeded $25 \mathrm{~mm}$, indicates a high sensitivity of microorganisms.

\section{Results}

Based on the results of the molecular docking we calculated the scoring function indicating the enthalpy contribution to the value of the free binding energy (Affinity DG) for the best conformation positions; the values of the free binding energy and binding constants (EDoc, $\mathrm{kcal} / \mathrm{mol}$ and $\mathrm{Ki}$ (uM, micromolar) for a definite conformational position of the ligand, which allowed us to evaluate the stability of complexes formed between ligands and the corresponding targets (Table 1).

Table 1

The values of Affinity DG, free binding energy, and binding coefficients for the best conformational positions of the test compounds in combination with biotargets (PDB ID: 2XCR, 5BTL, 4KPF)

\begin{tabular}{|c|c|c|c|c|c|c|c|c|c|}
\hline & \multicolumn{3}{|c|}{ 2XCR } & \multicolumn{3}{c|}{$5 \mathrm{BTL}$} & \multicolumn{3}{c|}{$4 \mathrm{KPF}$} \\
\cline { 2 - 10 } Molecule & $\begin{array}{c}\text { Affinity } \\
\mathrm{DG} \\
\mathrm{kcal} / \mathrm{mol}\end{array}$ & $\begin{array}{c}\text { EDoc, } \\
\mathrm{kcal} / \mathrm{mol}\end{array}$ & $\begin{array}{c}\mathrm{Ki}, \mathrm{uM} \mathrm{mi}- \\
\mathrm{cromolar}\end{array}$ & $\begin{array}{c}\text { Affini- } \\
\text { ty DG, } \\
\mathrm{kcal} / \\
\mathrm{mol}\end{array}$ & $\begin{array}{c}\text { EDoc, } \\
\mathrm{kcal} / \\
\mathrm{mol}\end{array}$ & $\begin{array}{c}\text { Ki uM } \\
\text { micromo- } \\
\text { lar }\end{array}$ & $\begin{array}{c}\text { Affini- } \\
\text { ty DG, } \\
\mathrm{kcal} / \\
\mathrm{mol}\end{array}$ & $\begin{array}{c}\text { EDoc, } \\
\mathrm{kcal} / \\
\mathrm{mol}\end{array}$ & $\begin{array}{c}\mathrm{Ki}, \mathrm{uM} \\
\mathrm{micromo} \\
\text { lar/ } \\
\mathrm{millimolar}\end{array}$ \\
\hline 1 & -7.3 & -4.51 & $497.66 \mathrm{uM}$ & -7.4 & -5.15 & $168.54 \mathrm{uM}$ & -7.2 & -4.56 & $457.42 \mathrm{uM}$ \\
\hline 2 & -7.8 & -4.71 & $352.12 \mathrm{uM}$ & -7.0 & -5.34 & $121.01 \mathrm{uM}$ & -6.8 & -4.18 & $867.01 \mathrm{uM}$ \\
\hline NOR & -7.2 & -4.30 & $708.28 \mathrm{uM}$ & -7.8 & -5.25 & $142.92 \mathrm{uM}$ & -7.4 & -4.78 & $315.73 \mathrm{uM}$ \\
\hline CIPRO & -7.2 & -5.10 & $183.79 \mathrm{uM}$ & -7.5 & -5.51 & $91.69 \mathrm{uM}$ & -7.4 & -5.38 & $113.52 \mathrm{uM}$ \\
\hline
\end{tabular}

Two synthetic routes (Fig. 2, 3) towards 7-(4-(2cyanoacetyl)piperazin-1-yl)-1-R-6-fluoro-4-oxo-1,4-dihy- droquinoline-3-carboxylic acids $(\mathbf{1}, \mathbf{2})$ were used and the preference was made for the one-step approach (Fig. 3). 
The structures of the obtained compounds were determined using elemental analysis, ${ }^{1} \mathrm{H}$ NMR, ${ }^{13} \mathrm{C}$ NMR, ${ }^{19}$ F NMR, LC/MS, IR-, UV- spectroscopy.

According to the results obtained by method of double serial dilutions the antimicrobial and antifungal activity of the synthesized compounds was at the control level.
Diffusion in agar method gave promising results against both reference and clinical strains of S. aureus and E. coli represented in Table 2. Growth retardation zone exceeded $25 \mathrm{~mm}$ which corresponds to the high sensitivity of microorganisms towards tested compounds.

Activity of the synthesized compounds against reference and clinical strains

\begin{tabular}{|c|c|c|c|c|c|c|}
\hline \multirow{3}{*}{ Compound } & \multicolumn{4}{|c|}{ Growth retardation zone, $\mathrm{mm}$} \\
\cline { 2 - 7 } & \multicolumn{3}{|c|}{ Reference strains } & \multicolumn{3}{c|}{ Clinical strains } \\
\cline { 2 - 7 } & \multirow{2}{*}{ S aureus ATCC 25923} & $\begin{array}{c}\text { E coli } \\
\text { ATCC } 25922\end{array}$ & $\begin{array}{c}\text { C albicans ATCC } \\
885-653\end{array}$ & \multirow{2}{*}{ S aureus } & E coli & C albicans \\
\hline 1 & $\mathbf{3 6 . 8} \pm \mathbf{1 . 3}$ & $\mathbf{4 0 . 4} \pm \mathbf{1 . 9}$ & $20.8 \pm 1.8$ & $\mathbf{3 1 . 4} \pm \mathbf{1 . 8}$ & $\mathbf{3 0 . 2} \pm \mathbf{1 . 7}$ & $14.9 \pm 1.6$ \\
\hline 2 & $\mathbf{3 4 . 2} \pm \mathbf{1 . 6}$ & $\mathbf{3 9 . 3} \pm \mathbf{1 . 7}$ & $21.9 \pm 1.5$ & $\mathbf{2 8 . 6} \pm \mathbf{1 . 8}$ & $\mathbf{3 0 . 8} \pm \mathbf{1 . 3}$ & $17.8 \pm 1.6$ \\
\hline Control & $24.2 \pm 1.8$ & $24.7 \pm 1.6$ & $20.5 \pm 1.34$ & $24.3 \pm 1.7$ & $24.4 \pm 1.8$ & $20.9 \pm 1.6$ \\
\hline
\end{tabular}

\section{Discussion}

Inhibitory activity of the tested molecules against antibacterial targets (PDB ID: 2XCR, 5BTL, 4KPF) can be achieved by the formation of complexes between them, the stability of which is provided mainly by energetically favourable geometric arrangement of ligands in active sites, formation of hydrogen bonds and interstitials, donor-acceptor interactions between them. As a result, the thermodynamic probability of such binding is confirmed by the negative values of the scoring function Afinity DG ( $\mathrm{kcal} / \mathrm{mol})$, the calculated values of free binding energy EDoc $(\mathrm{kcal} / \mathrm{mol})$ and the binding constants $\mathrm{Ki}(\mathrm{uM})$.

The obtained results revealed the fact that scoring functions do not always correlate with the values of free energies and binding constants, so in choosing the most promising compounds it is better to use comprehensive approach according to which 'hit molecules' possess minimal free energy values and constants (Table 1).
Based on the initial structures we can assume that the preservation of the fluorine atom in the 6th position and the piperazine system in the 7 th position with its subsequent substitution contribute to improved affinity. It should be mentioned that similar way towards new fluoroquinolones was previously described by authors [5].

Such in silico results led us to the idea that our target compounds could be further utilized for other modifications. According to the molecular docking that appears to be a promising way to combat antimicrobial resistance with modified fluoroquinolones that was our main aim.

That is why we need to develop the convenient synthetic procedure that will give sufficient yields of the target products being at the same time cost-effective and also environmentally friendly.

Among the possible synthetic routes at first the two-step procedure depicted on the Fig. 2 was used.

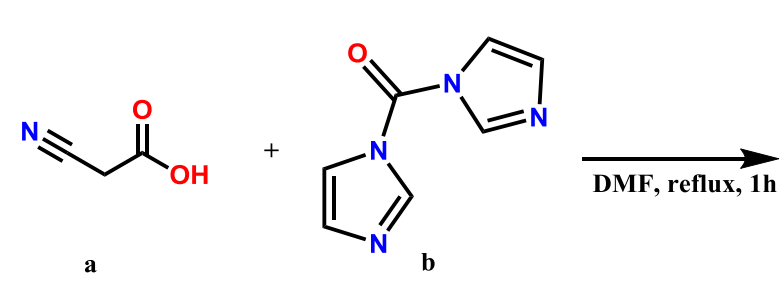<smiles>[R1]n1cc(C(=O)O)c(=O)c2cc(F)c(N3CCNCC3)cc21</smiles><smiles>[R7]n1cc(C(=O)O)c(=O)c2cc(F)c(N3CCN(C(=O)CC#N)CC3)cc21</smiles>

$R_{1}=$ Ethyl, Cyclopropyl

1,2

Fig. 2. Two-step approach to 7-(4-(2-cyanoacetyl)piperazin-1-yl)-1-R-6-fluoro-4-oxo-1,4-dihydroquinoline-3carboxylic acids ( 1 - ethyl, 2 - cyclopropyl)

It allows us to obtain target compounds $\mathbf{1}$ and $\mathbf{2}$ with $89 \%$ and $90 \%$ yield (after purification) respectively. However, it was associated with wide number of reagents and solvents that is against to the general principles of green chemistry [19, 20]. Additional amount of reagents was used for recrystallization.
Also it was necessary to purify the intermediate $\mathrm{N}$ (cyanoacetyl) imidazole $c$, which led to the prolongation of the procedure.

These issues were the reason to look for other options, mainly for one-step procedure, based on the experimental results for similar researchers $[9,11]$. 
At the next step of the research the reaction conditions were developed for the straight interaction of the initial fluoroquinolones with ethyl 2-cyanoacetate excess (Fig. 3). It appeared that under almost the same heating in DMF for 4 hours target compounds $\mathbf{1}$ and $\mathbf{2}$ were formed with $77 \%$ and $85 \%$ yield (after purification) respectively. Altogether though both synthetic methods gave the resulting compounds with the same structure and properties, the second procedure is definitely more easy and suitable.

The total time and the amount of the reagents needed are much smaller, which can be additionally proved by the calculations of the E-factor for the compound 1 synthesis (Table 3).<smiles>[R]n1cc(C(=O)O)c(=O)c2cc(F)c(N3CCNCC3)cc21</smiles>

$R_{1}=$ Ethyl, Cyclopropyl

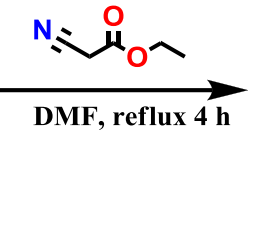

\section{$N$}<smiles>N#CCCCCCCCCCC#N</smiles><smiles>[R]n1cc(C(=O)O)c(=O)c2cc(F)c(N3CCN([Tl])CC3)cc21</smiles>

1,2

Fig. 3. One-step synthesis of the target compounds $\mathbf{1 , 2}$

Table 3

E-factors for the two-step and one-step synthetic procedures for compound 1

\begin{tabular}{|c|c|c|}
\hline Compound & $\begin{array}{l}\text { Two-step ap- } \\
\text { proach }\end{array}$ & $\begin{array}{l}\text { One-step ap- } \\
\text { proach }\end{array}$ \\
\hline \multicolumn{3}{|l|}{ The first step } \\
\hline 2-cyanoacetic acid & $\begin{array}{c}85.06 \mathrm{~g} / \mathrm{mol} \\
100 \mathrm{mmol} \\
8.5 \mathrm{~g}\end{array}$ & - \\
\hline CDI & $\begin{array}{c}162.15 \mathrm{~g} / \mathrm{mol} \\
120 \mathrm{mmol} \\
19.5 \mathrm{~g} \\
\end{array}$ & - \\
\hline DMF & $100 \mathrm{ml}(94.45 \mathrm{~g})$ & - \\
\hline \multicolumn{3}{|l|}{ The second step } \\
\hline $\begin{array}{l}\text { 1-ethyl-6-fluoro-4-oxo-7-(piperazin-1-yl)-1,4-dihydroquinoline-3-carboxylic } \\
\text { acid } 1\end{array}$ & $\begin{array}{c}319.33 \mathrm{~g} / \mathrm{mol} \\
30 \mathrm{mmol} \\
9.6 \mathrm{~g} \\
\end{array}$ & $\begin{array}{c}319.33 \mathrm{~g} / \mathrm{mol} \\
30 \mathrm{mmol} \\
9.6 \mathrm{~g} \\
\end{array}$ \\
\hline $\mathrm{N}$-(cyanoacetyl)imidazole & $\begin{array}{c}135 \mathrm{~g} / \mathrm{mol} \\
90 \mathrm{mmol} \\
12.1 \mathrm{~g}\end{array}$ & - \\
\hline Ethyl 2-cyanoacetate & - & $\begin{array}{c}112.11 \mathrm{~g} / \mathrm{mol} \\
90 \mathrm{mmol} \\
10.1 \mathrm{~g} \\
\end{array}$ \\
\hline DMF & $100 \mathrm{ml}(94.45 \mathrm{~g})$ & $100 \mathrm{ml}(94.45 \mathrm{~g})$ \\
\hline $\mathrm{MeOH}$ & $100 \mathrm{ml}(79.18 \mathrm{~g})$ & $100 \mathrm{ml}(79.18 \mathrm{~g})$ \\
\hline Total amount & $305.7 \mathrm{~g}$ & $193.3 \mathrm{~g}$ \\
\hline Yield of product & $\begin{array}{c}89 \% \\
386.38 \mathrm{~g} / \mathrm{mol} \\
10.3 \mathrm{~g}\end{array}$ & $\begin{array}{c}77 \% \\
386.38 \mathrm{~g} / \mathrm{mol} \\
8.9 \mathrm{~g}\end{array}$ \\
\hline Amount of wastes & $295.4 \mathrm{~g}$ & $184.4 \mathrm{~g}$ \\
\hline E-factor & 28.7 & 20.7 \\
\hline
\end{tabular}

As the obtained compounds $(\mathbf{1 , 2})$ revealed antimicrobial and antifungal activity at the control level in dilution method and exceeded control in 'well' method, one can assume that such structural modification is highly promising and can be also considered as a first step for further changes.

Before utilizing other chemical methods, it would be reasonable to provide further docking studies and check the properties of possible substituents and their influence on binding modes of the initial fluoroquinolones molecules.

Study limitations. There are some limitations for the serial dilution method, which could influence the ob- tained results. This technique is performed in a stepwise manner with extended period of the study. This limits the efficiency because the prepared environments must be utilized immediately.

Prospects for further research. The 4-(2cyanoacetyl)piperazin-1-yl moiety opens further opportunities to introduce different heterocyclic fragments in the initial fluoroquinolone ring. As now we have developed convenient method towards 7-(4-(2-cyanoacetyl)piperazin1-yl)-1-R-6-fluoro-4-oxo-1,4-dihydroquinoline-3-carboxylic acids, our further steps are going to be concerned with cyclization reactions based on the new substituents. It is also 
advisable to expand the range of microorganisms that will be used through our next screenings.

\section{Conclusions}

Novel scaffolds for future synthesis of ciprofloxacin and norfloxacin hybrids - 7-(4-(2-cyanoacetyl)piperazin-1yl)-1-R-6-fluoro-4-oxo-1,4-dihydroquinoline-3-carboxylic acids were designed and investigated.

1. The molecular docking studies for the designed compounds showed Affinity DG (kcal/mol) and the calculated values of free binding energy EDoc on the level of Ciprofloxacin and Norfloxacin.

2 . The efficient and simple method for the synthesis of novel 7-(4-(2-cyanoacetyl)piperazin-1-yl)-1-R-6-fluoro4-oxo-1,4-dihydroquinoline-3-carboxylic acids was developed. The structure and purity of the obtained compounds were confirmed by ${ }^{1} \mathrm{H}$ NMR, ${ }^{13} \mathrm{C}$ NMR, ${ }^{19} \mathrm{~F}$ NMR, LC/MS, UV-, IR- spectroscopy.
3. The antibacterial research of 7-(4-(2-cyanoacetyl)piperazin-1-yl)-1-R-6-fluoro-4-oxo-1,4-dihydroquinoline-3-carboxylic acids revealed antimicrobial and antifungal activities at the reference level for double dilution method and exceeded control for "well" method. This fact proves their ability to be further utilized against drug-resistant bacteria.

\section{Conflict of interest}

The authors declare that they have no conflicts of interest.

\section{Financing}

Research was funded by the Ministry of Health of Ukraine from the state budget according to the topic "Molecular design and microbiological screening of innovative derivatives of fluoroquinolone antibiotics in order to combat resistant strains of microorganisms" (state registration number: 0121U109239).

\section{References}

1. The evolving threat of antimicrobial resistance. Options for action. WHO. Available at: http://apps.who.int/iris/bitstream/handle/ 10665/44812/9789241503181_eng.pdf?sequence=1

2. Polk, R. E., Fox, C., Mahoney, A., Letcavage, J., MacDougall, C. (2007). Measurement of Adult Antibacterial Drug Use in 130 US Hospitals: Comparison of Defined Daily Dose and Days of Therapy. Clinical Infectious Diseases, 44 (5), 664-670. doi: http://doi.org/10.1086/511640

3. Birnbaum, D. (2003). Resistance CCoA. Antimicrobial resistance: a deadly burden no country can afford to ignore. Canada Communicable Disease Report, 29 (18), 157-164.

4. Feshchenko, Yu. I., Humeniuk, M. I., Denysov, O. S. (2010). Antybiotykorezystentnist mikroorhanizmiv. Stan problemy ta shliakhy vyrishennia. Ukrainskyi khimioterapevtychnyi zhurnal, 1-2 (23), 4-10.

5. Suaifan, G. A. R. Y., Mohammed, A. A. M. (2019). Fluoroquinolones structural and medicinal developments (20132018): Where are we now? Bioorganic \& Medicinal Chemistry, 27 (14), 3005-3060. doi: http://doi.org/10.1016/j.bmc.2019.05.038

6. Bush, N. G., Diez-Santos, I., Abbott, L. R., Maxwell, A. (2020). Quinolones: Mechanism, Lethality and Their Contr?butions to Antibiotic Resistance. Molecules, 25 (23), 5662. doi: http://doi.org/10.3390/molecules25235662

7. Dalhoff, A. (2012). Global Fluoroquinolone Resistance Epidemiology and Implictions for Clinical Use. Interdisciplinary Perspectives on Infectious Diseases, 2012, 1-37. doi: http://doi.org/10.1155/2012/976273

8. Fasugba, O., Gardner, A., Mitchell, B. G., Mnatzaganian, G. (2015). Ciprofloxacin resistance in community- and hospitalacquired Escherichia coli urinary tract infections: a systematic review and meta-analysis of observational studies. BMC Infectious Diseases, 15 (1). doi: http://doi.org/10.1186/s12879-015-1282-4

9. Savchenko, T. I., Silin, O. V., Kovalenko, S. M., Musatov, V. I., Nikitchenko, V. M., Ivachtchenko, A. V. (2007). Alkyl?tion of 3-Phenyl-1H-pyrazolo[4,3-c] quinoline: Theoretical Analysis of Regioselectivity. Synthetic Communications, 37 (8), $1321-$ 1330. doi: http://doi.org/10.1080/00397910701227077

10. Ivachtchenko, A., Silin, O., Savchenko, T., Kovalenko, S., Nikitchenko, V. (2004). Synthesis of 5H-Pyrazolo[4,3c]quinolines. Heterocycles, 63 (8), 1883-1890. doi: http://doi.org/10.3987/com-04-10092

11. Bylov, I. E., Bilokin, Y. V., Kovalenko, S. M. (1999). Specific Features of Reactions of 2-Aminobenzotrifluoride and Anthranilates with Ethyl Cyanoacetate - Expeditious Routes to 3-Substituted 4-Amino- and 4-Hydroxyquinolin-2(1H)-Ones. Heterocyclic Communications, 5 (3). doi: http://doi.org/10.1515/hc.1999.5.3.281

12. Naidu, K. M., Nagesh, H. N., Singh, M., Sriram, D., Yogeeswari, P., Gowri Chandra Sekhar, K. V. (2015). Novel amide and sulphonamide derivatives of 6-(piperazin-1-yl)phenanthridine as potent Mycobacterium tuberculosis H37Rv inhibitors. European Journal of Medicinal Chemistry, 92, 415-426. doi: http://doi.org/10.1016/j.ejmech.2015.01.013

13. Black, T. A., Mcnicholas, P. M., Walker, S. S., Xu, Y., Ting, P. C. (2008). Pat. WO2008115385A2. Piperazinesubstituted pyridazinone derivatives useful as glucan synthase inhibitors. Available at: https://patents.google.com/patent/ WO2008115385A2/en

14. Pushpan, S., Ramachandran, U., Kundu, M., Anantharaman, V., Subramanian, S., Viswanathan R., Tadiparthi, R. et. al. (2008). Novel compounds and their use. Pat. WO2009001192A2. Available at: https://patents.google.com/patent/WO2009001192A2/en

15. Mohapatra, R. K., El-ajaily, M. M., Alassbaly, F. S., Sarangi, A. K., Das, D., Maihub, A. A. et. al. (2020). DFT, anticancer, antioxidant and molecular docking investigations of some ternary $\mathrm{Ni}$ (II) complexes with 2-[(E)-[4-(dimethylamino)phenyl]methyleneamino]phenol. Chemical Papers, 75 (3), 1005-1019. doi: http://doi.org/10.1007/s11696-020-01342-8

16. Mohapatra, R. K., Perekhoda, L., Azam, M., Suleiman, M., Sarangi, A. K., Semenets, A. et. al. (2021). Computational investigations of three main drugs and their comparison with synthesized compounds as potent inhibitors of SARS-CoV-2 main protease (Mpro): DFT, QSAR, molecular docking, and in silico toxicity analysis. Journal of King Saud University - Science, 33 (2), 101315. doi: http://doi.org/10.1016/j.jksus.2020.101315

17. Volianskyi, Yu. L., Hrytsenko, I. S., Shyrobokov, V. P. (2004). Vyvchennia spetsyfichnoi aktyvnosti protymikrobnykh likarskykh zasobiv. Kyiv: DFTs MOZ Ukrainy, 38.

18. Vyznachennia chutlyvosti mikroorhanizmiv do antybakterialnykh preparativ (2007). Metodychni vkazivky, 70.

19. Sheldon, R. A. (2012). Fundamentals of green chemistry: efficiency in reaction design. Chemical Society Reviews, 41 (4), 1437-1451. doi: http://doi.org/10.1039/c1cs15219j 
20. Sheldon, R. A. (2019). The greening of solvents: Towards sustainable organic synthesis. Current Opinion in Green and Sustainable Chemistry, 18, 13-19. doi: http://doi.org/10.1016/j.cogsc.2018.11.006

Received date 10.08.2021

Accepted date 12.10.2021

Published date 29.10.2021

Halyna Hryhoriv, PhD, Department of Pharmaceutical Chemistry, National University of Pharmacy, Pushkinska str., 53, Kharkiv, Ukraine, 61002

Illia Mariutsa, Postgraduate Student, Department of Organic Chemistry, National University of Pharmacy, Pushkinska str., 53, Kharkiv, Ukraine, 61002

Sergiy M. Kovalenko, Doctor of Chemical Sciences, Professor, Department of Organic Chemistry, V. N. Karazin Kharkiv National University, Svobody sq., 4, Kharkiv, Ukraine, 61022

Lyudmila Sidorenko, Doctor of Pharmaceutical Sciences, Professor, Department of Pharmaceutical Chemistry, National University of Pharmacy, Pushkinska str., 53, Kharkiv, Ukraine, 61002

Lina Perekhoda, Doctor of Pharmaceutical Sciences, Professor, Department of Medicinal Chemistry, National University of Pharmacy, Pushkinska str., 53, Kharkiv, Ukraine, 61002

Nataliia Filimonova, Doctor of Medical Sciences, Professor, Department of Microbiology, Virology and Immunology, National University of Pharmacy, Pushkinska str., 53, Kharkiv, Ukraine, 61002

Olga Geyderikh, PhD, Associate Professor, Department of Microbiology, Virology and Immunology, National University of Pharmacy, Pushkinska str., 53, Kharkiv, Ukraine, 61002

Victoriya Georgiyants*, Doctor of Pharmaceutical Sciences, Professor, Department of Pharmaceutical Chemistry, National University of Pharmacy, Pushkinska str., 53, Kharkiv, Ukraine, 61002

*Corresponding author: Halyna Hryhoriv, e-mail: galkagrigoriv@gmail.com 